\title{
Colletotrichum fragariae Is a Pathogen on Hosts Other Than Strawberry
}

\author{
S. J. MacKenzie, J. C. Mertely, T. E. Seijo, and N. A. Peres, University of Florida, Gulf Coast Research and Edu- \\ cation Center, Wimauma 33598
}

\begin{abstract}
MacKenzie, S. J., Mertely, J. C., Seijo, T. E., and Peres, N. A. 2008. Colletotrichum fragariae is a pathogen on hosts other than strawberry. Plant Dis. 92:1432-1438.

Evidence that Colletotrichum fragariae causes disease on hosts other than strawberry is limited. In the fall of 2006, fungal isolates from silver date palm with leaf spot symptoms and from cyclamen with leaf spot and stem rot symptoms were identified as $C$. fragariae. After confirming the pathogenicity of the isolates on their host of origin, a representative isolate from each host was compared to $C$. fragariae and to $C$. gloeosporioides/Glomerella cingulata isolates from strawberry. Date palm and cyclamen isolates bore conidia on setae, and conidia were tapered and in the size range of $C$. fragariae reference isolates. Sequence data from the combined internal transcribed spacer (ITS) regions 1 and 2 and the gene for the 5.8 ribosomal RNA from the cyclamen and date palm isolates matched the sequence for $C$. fragariae reference isolates. Based on these characteristics, it was concluded that the $C$. fragariae species designation was correct for both isolates. However, the date palm isolate was a weak pathogen on strawberry compared with other isolates and had a distinct AT-rich DNA banding pattern. The ability of the cyclamen isolate to cause crown rot on strawberry was comparable with the strawberry reference isolates, and the AT-rich DNA banding pattern of the cyclamen isolate was identical to the $C$. fragariae isolates from strawberry. The results indicate that $C$. fragariae is a pathogen on hosts other than strawberry and that there is more diversity among $C$. fragariae isolates than previously reported.
\end{abstract}

Additional keywords: anthracnose, Colletotrichum crown rot, Cyclamen persicum, Phoenix sylvestris

Evidence that Colletotrichum fragariae Brooks is a pathogen on hosts other than strawberry is limited. In 1973, Cassia obtusifolia was described as a reservoir of Colletotrichum fragariae in Florida (11). Later, Gunnell and Gubler (10) recognized that isolates identified as $C$. fragariae could be split into two groups based on morphological characteristics, and assigned isolates belonging to one of these groups to $C$. gloeosporioides (Penz.) Penz. \& Sacc. (teleomorph: Glomerella cingulata (Stoneman) Spauld. \& H. Schenk). Arbitrarily primed polymerase chain reaction (PCR) banding patterns, AT-rich DNA markers $(7,8)$, and sequence from the internal transcribed spacer (ITS) region of

Corresponding author: S. J. MacKenzie E-mail: sjmac@ufl.edu

GenBank accession numbers EU408781, EU408782, EU408783, and EU408784 (submitted for this publication); EF177477, DQ868489, and DQ868498 (previously submitted); and American Type Culture Collection accession numbers MYA4442 and MYA-4443 (submitted for this publication).

* The $\boldsymbol{e}$-Xtra logo stands for "electronic extra" and indicates that Figure 1 appears in color in the online edition.

Accepted for publication 12 June 2008.

doi:10.1094/PDIS-92-10-1432

(c) 2008 The American Phytopathological Society the gene encoding the ribosomal RNA (rDNA) repeat (23) supported the morphological groupings of Gunnell and Gubler and also showed that homothallic G. cingulata isolates that cause disease on strawberry (12) can be differentiated from selfsterile $C$. gloeosporioides isolates. At present, self-sterile $C$. gloeosporioides isolates are most frequently obtained from plants with Colletotrichum crown rot in Florida, and isolates genetically indistinguishable from those from strawberry can be found on a broad range of noncultivated hosts throughout the state $(15,27,31)$. Therefore, it is possible that the isolates obtained from Cassia obtusifolia were actually Colletotrichum gloeosporioides. An isolate classified as $C$. fragariae was recently obtained from an oak leaf lesion in Florida (15). Based on randomly amplified polymorphic DNA (RAPD) markers, this isolate clustered with a $C$. fragariae isolate from strawberry and there was only a single base pair insertion within a cytosine repeat of the ITS region that distinguished this isolate from a $C$. fragariae isolate from strawberry. Furthermore, the isolate was an aggressive pathogen on strawberry (14). Although the isolate was obtained from a lesion on oak approximately $28 \mathrm{~km}$ from a strawberry field, pathogenicity to oak could not be confirmed. Perhaps the best evidence that $C$. fragariae is a pathogen on a host other than strawberry comes from a description of isolates from anthracnose-affected cherimoya fruit (28). These isolates had morphological characteristics consistent with the description for $C$. fragariae, and there was only a single base pair mismatch between cherimoya isolates and $C$. fragariae isolates from strawberry within the ITS1 region of the rDNA repeat. Although it appears that the isolates from cherimoya were identified correctly, their pathogenicity was not tested on strawberry, nor was a more rapidly evolving marker than the ITS region used to evaluate strains. The latter is important because within the $C$. gloeosporioides/G. cingulata species aggregate, some isolate groups with identical ITS sequences can be differentiated by RAPD banding patterns (15). Based on ITS1 sequence data, several benomyl-sensitive $C$. gloeosporioides isolates from statice ( $\mathrm{Li}$ monium spp.) in Israel grouped with $C$. fragariae isolates (16). However, the isolates were classified as $C$. gloeosporioides because they produced conidia that were cylindrical with rounded ends, as opposed to being tapered like $C$. fragariae conidia, and conidia were not borne on setae.

C. fragariae was first isolated and described from Florida-grown strawberry plants with anthracnose symptoms on runners and petioles in 1931 (1). Four years later, the fungus was also reported to cause wilting of strawberry plants (2). In the initial description of $C$. fragariae, isolates produced setae with a small, slightly constricted apical cell and conidia described as spindle- to boat-shaped with rounded ends. The isolates did not produce disease symptoms on alfalfa, hollyhock, red clover, snap dragon, spinach, and string bean, plant species that were hosts of morphologically similar Colletotrichum spp., and no ascigerous stage was found. In an updated description of $C$. fragariae by Gunnell and Gubler (10), they reported that $C$. fragariae isolates possess setae that function as phialides in addition to producing conidia in acervuli. They also described the shape of conidia as being tapered at one end. As previously mentioned, many if not all C. gloeosporioides isolates from strawberry were described as $C$. fragariae prior to the updated species definition of Gunnell and Gubler (10). Although the group of isolates from strawberry designated $C$. fragariae is currently well defined, there is disagreement regarding whether $C$. $f r a-$ gariae should be included within C. gloeosporioides because, within this species, there are strains more distantly related to one another than they are to $C$. fragariae $(5,18,24)$. Also, self-sterile C. gloeo- 
sporioides strains continue to be described as $C$. fragariae in the literature, contributing to the uncertainty regarding the taxonomic status of $C$. fragariae $(4,23)$. In the present study, we assume that an isolate is C. fragariae if it matches the morphological description of Gunnell and Gubler (10) and the sequence from the ITS region of the rDNA repeat matches the sequence of this genomic region from reference strawberry isolates identified as $C$. fragariae.

During fall 2006, a fungus matching the species description for $C$. fragariae was repeatedly isolated from diseased silver date palms (Phoenix sylvestris (L.) Roxb.) and cyclamen (Cyclamen persicum Mill.) grown at two different nurseries in Florida. In the current study, representative isolates from silver date palm and cyclamen were inoculated onto their host of origin to confirm that the isolates were responsible for symptoms observed on nursery plants. After confirming that the isolates caused disease, morphological characteristics, ITS data, AT-rich DNA banding patterns, and a pathogenicity assay on strawberry were used to compare the palm and cyclamen isolates with reference Colletotrichum fragariae and C. gloeosporioides/G. cingulata isolates from strawberry.

\section{MATERIALS AND METHODS}

Colletotrichum isolates and source of isolates. Isolates used in the study are listed in Table 1. Strawberry reference isolates included $C$. fragariae isolates and the two $C$. gloeosporioides/G. cingulata strains identified by Freeman et. al. (7) that cause disease on strawberry. Isolates 311-1 and 326-1 were collected by Charles $\mathrm{M}$. Howard (University of Florida Gulf Coast Research and Education Center, Dover). Isolate $326-1$ is a $C$. fragariae isolate from strawberry included in Gunnell and Gubler's publication (10) updating the $C$. fragariae species description. Isolate $311-1$ is a $G$. cingulata isolate also described in that publication. Freeman et al. (7) reported that $C$. gloeosporioides or $G$. cingulata isolates from strawberry displayed two distinct AT-rich DNA fingerprints referred to as genotypes Cgl-1 and Cgl-2. Isolate 311-1 has a Cgl-1 genotype. An AT-rich DNA fingerprint for isolate 326-1 was not reported in the Freeman et al. study (7); however, this isolate grouped with $C$. fra- gariae isolates used in that study when Colletotrichum spp. on strawberry were differentiated by arbitrarily primed PCR (8). A visual comparison of the AT-rich banding pattern of $C$. fragariae isolates in Freeman et al. (7) to the AT-rich DNA banding pattern of isolate 326-1 also confirmed that this served as a suitable reference. Other isolates from strawberry plants with crown rot include strawberry-11, strawberry-6, and C-16, described previously $(14,15,31)$. Isolate C-16 is a $C$. fragariae isolate recently obtained from crown tissue of a diseased strawberry plant (14). Isolates strawberry-11 and strawberry-6 are $\mathrm{Cgl}-2$ genotype $C$. gloeosporioides isolates based on AT-rich DNA fingerprints (7) each possessing one of the two ITS rDNA genotypes observed among Cgl-2 type isolates (15).

Isolates from silver date palm (06-59) and cyclamen (06-69) were obtained from infected plants submitted to the diagnostic clinic at the University of Florida Gulf Coast Research and Education Center (GCREC) in Wimauma during fall 2006. The silver date palm isolate came from a nursery in Plant City, FL and the cyclamen isolate from a nursery in Bradenton, FL. Isolations were made by surface disinfesting foliar lesions with $0.525 \%$ sodium hypochlorite for $1 \mathrm{~min}$, rinsing in sterile water, and placing the infected tissue onto antibiotic-supplemented potato dextrose agar (PDA; potato dextrose agar at 19.5 $\mathrm{g} /$ liter, agar at $9.5 \mathrm{~g} /$ liter, streptomycin at $0.1 \mathrm{~g} /$ liter, and ampicillin at $0.25 \mathrm{~g} /$ liter). Single-spore isolates were obtained after cultures were incubated under continuous fluorescent light at $25^{\circ} \mathrm{C}$ for approximately 5 days. Symptoms observed on silver date palm at the time of collection were numerous small leafspots less than $3 \mathrm{~mm}$ in diameter with reddish-tan centers and darkgray, water-soaked borders. On cyclamen, symptoms consisted of large, dark leaf spots starting at leaf margins and basal rot. The growers estimated that over $50 \%$ of the silver date palms and $80 \%$ of the cyclamens in their nurseries had disease symptoms. Cercospora-like conidiophores were observed protruding from lesions on both hosts. These structures were later found to be setae bearing conidia. Acervuli were also present on cyclamen. A Colletotrichum sp. was isolated repeatedly from lesions on both hosts. The isolates 06-59 and 06-69 are representative of the strains isolated from silver date palm and cyclamen, respectively. These isolates were deposited in the American Type Culture Collection (Manassas, VA) under the accession numbers MYA-4442 (06-59) and MYA-4443 (06-69).

Morphology and pathogenicity. Digital images of setae from infected host material and conidia from 5-day-old cultures grown on PDA were taken at $\times 400$ magnification using an Olympus BX41 microscope and Olympus Q-Color5 imaging system (Olympus Corporation, Tokyo). Conidial measurements were made using the image analysis software program Assess (2002 version; American Phytopathological Society Press, St. Paul, MN). The length and maximum width of 25 conidia were measured for each isolate. Mean conidium lengths and widths of isolates were compared using a series of $t$ tests under the assumption that variances were not the same for the isolates being compared. Means were grouped if $P>t$ was greater than 0.05 . From each isolate, the shape of 50 conidia was classified as either cylindrical or tapered. A conidium was classified as cylindrical if one side of the conidium was parallel to the other side down the length of the conidium. If the width of one end of the conidium was greater than the other, the conidium was classified as tapered. The proportions of tapered conidia produced by isolates were compared using a series of single-degreeof-freedom $\chi^{2}$ tests. Isolates were grouped if $P>\chi^{2}$ was greater than 0.05 . The $\chi^{2}$ and $t$ tests were performed using the software package Statistix 8.1 (Analytical Software, Tallahassee, FL).

Pathogenicity of isolate $06-59$ on date palm was tested by spraying immature leaves on three seedlings with a suspension of $1 \times 10^{6}$ conidia $/ \mathrm{ml}$. Three control plants were sprayed with water. All seedlings were covered with plastic bags and incubated for $24 \mathrm{~h}$ at $28^{\circ} \mathrm{C}$. After removal of bags, plants were monitored for symptoms in a growth chamber at $28^{\circ} \mathrm{C}$ for 4 weeks. Only simple-shaped leaves were treated, because plants received with disease symptoms at the clinic had no pinnate leaves. Pathogenicity of isolate 06-69 on cyclamen was tested by spraying three mature, flow-

Table 1. Description of Colletotrichum fragariae, C. gloeosporioides, and Glomerella cingulata isolates used to characterize Colletotrichum isolates from diseased silver date palm and cyclamen

\begin{tabular}{|c|c|c|c|c|c|c|}
\hline Species & Isolate & Host & Location & Year & GenBank accession & References \\
\hline G. cingulata & $311-1$ & Strawberry & Dover/Plant City, FL & 1987 & EU408781 & $7,8,10,23$ \\
\hline C. gloeosporioides & Strawberry-6 & Strawberry & Dover/Plant City, FL & 1996 & EF177477 & 15 \\
\hline C. gloeosporioides & Strawberry-11 & Strawberry & Dover/Plant City, FL & 1996 & DQ868489 & 15 \\
\hline C. fragariae & $326-1$ & Strawberry & Dover/Plant City, FL & 1988 & DQ868498 & $8,10,15$ \\
\hline C. fragariae & C-16 & Strawberry & Dover/Plant City, FL & 2002 & EU408784 & 14 \\
\hline C. fragariae & $06-59^{z}$ & Silver date palm & Plant City, FL & 2006 & EU408782 & This study \\
\hline C. fragariae & $06-69^{z}$ & Cyclamen & Bradenton, FL & 2006 & EU408783 & This study \\
\hline
\end{tabular}

${ }^{\mathrm{z}}$ Isolates 06-59 and 06-69, newly described in this study, were deposited in the American Type Culture Collection under accession numbers MYA-4442 and MYA-4443, respectively. 
ering plants with a $5 \times 10^{5}$ conidia/ml suspension. Two control plants were sprayed with water. Seedlings were covered with plastic bags and incubated in a greenhouse $\left(13\right.$ to $\left.27^{\circ} \mathrm{C}\right)$ for $16 \mathrm{~h}$. After removal of the bags, plants remained in a greenhouse and were monitored for symptoms for 14 days. Spore suspensions were prepared by suspending conidia from 1week-old cultures in sterile deionized water and passing the suspensions through four layers of cheesecloth. Conidia were counted using a hemacytometer and concentrations adjusted with sterile water. Reisolations were made from the plants to confirm that isolates were responsible for the symptoms.

Each isolate listed in Table 1 was used to inoculate 10 strawberry plants (cv. Strawberry Festival) during fall 2007 in Wimauma, FL. Spore suspensions were prepared as described above. Four plants were inoculated on one date and three plants were inoculated on two additional dates. On each date, $100 \mu \mathrm{l}$ of a $1 \times 10^{6}$ conidia/ml spore suspension was injected into crown tissue using a 25-gauge syringe needle. This technique has been shown previously to differentiate isolates with the ability to produce strawberry crown rot (15). Once inoculated, plants remained in a greenhouse for 32 days at temperatures that fluctuated from 10 to $29^{\circ} \mathrm{C}$. Every fourth day, plants were evaluated for crown rot symptoms and, for collapsed plants, the time from inoculation to collapse was re- corded. At the end of the 32-day interval, the number of collapsed plants and the number of plants remaining alive was recorded for each isolate and the experiment was terminated. Controls consisted of 10 plants injected with sterile water, 4 on one date and 3 on the two other dates. For statistical analyses, if a plant was alive at 32 days, the time it took for the plant to collapse was coded as 33 days. Data, after being converted to ranks, were analyzed using a nonparametric method for two-way factorial experiments (20). In this analysis, the effect of isolate, inoculation date, and isolate $x$ inoculation date were evaluated using a program written in SAS (SAS Institute, Cary, NC). Effects were evaluated based on probability values of the analysis of variance-type statistic (ATS), a statistic with an approximate $F$ distribution that provides robust inferences in designs with a normal heteroscedastic error structure (3). Paired comparisons of isolates were made using the contrast statement and grouped if the probability of the ATS for the paired comparison exceeded 0.05 .

Genetic analysis. Mycelia were collected from 2- to 4-day-old cultures grown in $100 \mathrm{ml}$ of Emerson media (yeast extract at $4 \mathrm{~g} /$ liter, soluble starch at $15 \mathrm{~g} /$ liter, $\mathrm{K}_{2} \mathrm{HPO}_{4}$ at $1 \mathrm{~g} /$ liter, and $\mathrm{MgSO}_{4}$ at 0.5 $\mathrm{g} /$ liter) by vacuum filtration through Whatman no. 3 filter paper and dried overnight in a centrifugal evaporator. DNA was extracted from $60 \mathrm{mg}$ of the dried mycelia using a previously published cetyl- trimethylammonium bromide procedure (31). Primer ITS1 (5'-TCCGTAGGTGAA CCTGCGG-3'), which anneals to the gene encoding the small-subunit rRNA, and ITS4 (5'-TCCTCCGCTTATTGATATGC$3^{\prime}$ ), which anneals to the gene encoding the large-subunit rRNA, were used to amplify a 574- to 578-bp DNA fragment containing portions of the $18 \mathrm{~S}$ and $28 \mathrm{~S}$ rRNA genes and the entire ITS1 region, the 5.8S rRNA gene, and ITS2 region from isolates 311-1, C-16, 06-59, and 06-69 (29). Amplifications from template DNA (5 ng) were carried out in a $120-\mu$ l volume containing $1 \times$ reaction buffer $(10 \mathrm{mM}$ Tris $[\mathrm{pH} 9], 50$ $\mathrm{mM} \mathrm{KCl}$, and $\left.2 \mathrm{mM} \mathrm{MgCl}_{2}\right), 200 \mu \mathrm{M}$ dNTP, 5 units of Taq polymerase, and 60 pmol of each primer per reaction. Cycling parameters consisted of a 4-min denaturing step at $94^{\circ} \mathrm{C}$ followed by 34 cycles at $94^{\circ} \mathrm{C}$ for $45 \mathrm{~s}, 52^{\circ} \mathrm{C}$ for $45 \mathrm{~s}$, and $72^{\circ} \mathrm{C}$ for 1 min. DNA from amplifications was concentrated using a Microcon YM-30 centrifugal filter (Millipore, Billerica, MA) to $20 \mathrm{ng} / \mu \mathrm{l}$, and $15-\mu \mathrm{l}$ samples were submitted to the University of Florida Interdisciplinary Center for Biotechnology Research in Gainesville for sequencing. Sequence data were generated in forward and reverse directions from fluorescent cycle sequencing reactions using an automated sequencer (Perkin Elmer/Applied Biosystems, Foster City, CA). Sequence data for isolates 326-1, strawberry-11, and strawberry- 6 were generated in a previous study (15). Alignments were done using
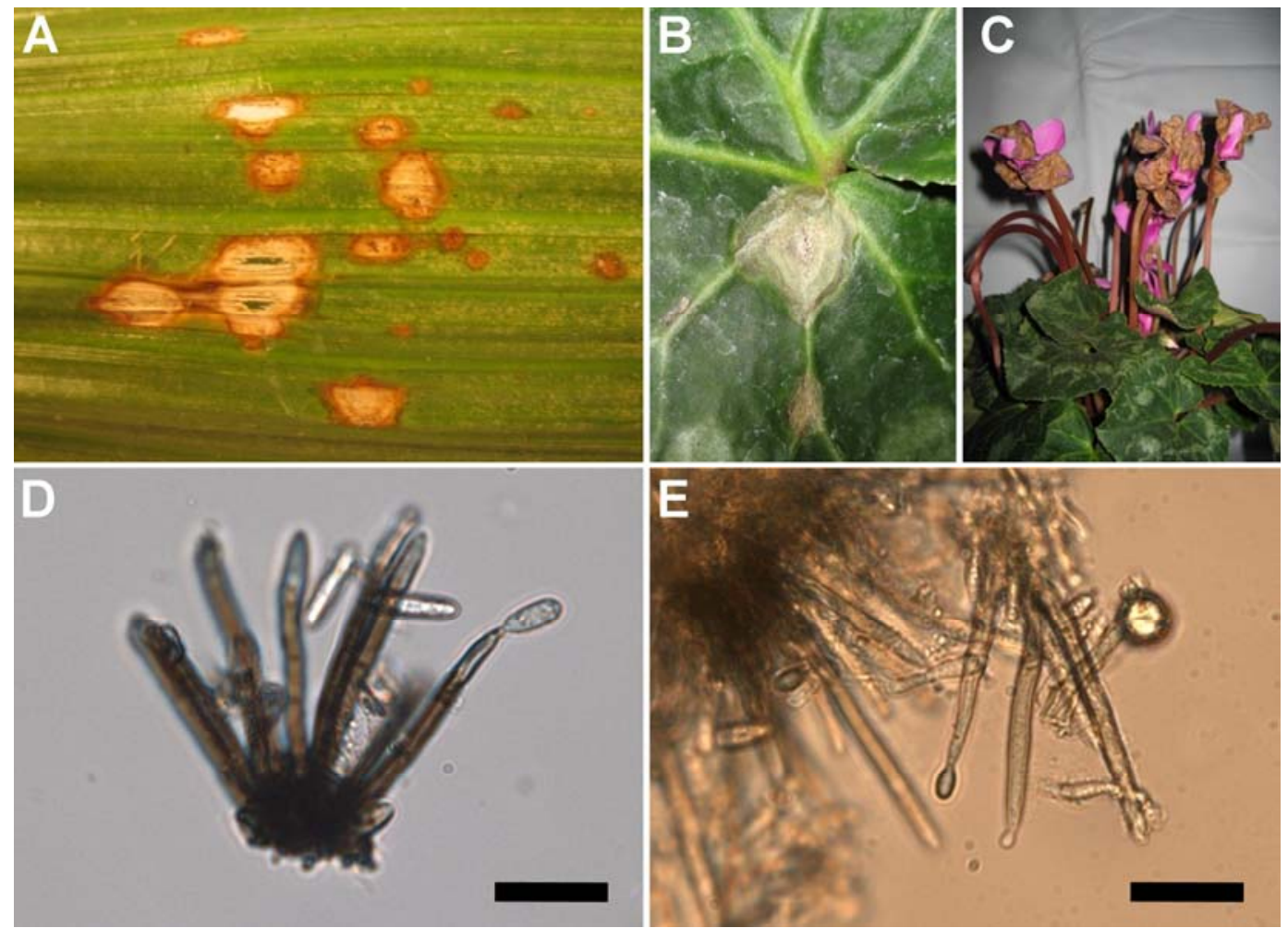

Fig. 1. Symptoms observed on plants inoculated with a suspension of conidia from Colletotrichum fragariae isolates 06-59 or 06-69. A, Leaf spot symptoms observed on silver date palm inoculated with silver date palm isolate 06-59 at 28 days post inoculation. B, Leaf lesion on cyclamen inoculated with cyclamen isolate 06-69 at 10 days post inoculation. C, Severe flower blight on cyclamen plants inoculated with cyclamen isolate 06-69 at 10 days post inoculation. D, Setae bearing conidia of isolate 06-59 from silver date palm. E, Setae bearing conidia of isolate 06-69 from cyclamen. Bar $=25 \mu \mathrm{m}$. 
CLUSTALW (25). The ITS1 region, the 5.8S ribosomal RNA gene, and ITS2 region were annotated from sequences reported for the small-subunit (GenBank accession X04971) (22) and 5.8S subunit rRNA (GenBank accession M10692) (19) of Neurospora crassa and the large-subunit rRNA of Saccharomyces cerevisiae (GenBank accession J01355) (9). The combined length of the three regions ranged from 485 to $489 \mathrm{bp}$ for all isolates used in the study. AT-rich DNA bands were identified by digesting $3 \mu \mathrm{g}$ of genomic DNA with the restriction enzyme HaeIII (30). Digested DNA was separated on a $1 \%$ agarose gel in $1 \times$ Tris-borate-EDTA buffer for $24 \mathrm{~h}$ at $40 \mathrm{~V}$ and stained with ethidium bromide. This procedure was repeated twice with genomic DNA from separate isolations. Successful differentiation of Colletotrichum spp. and subpopulations within species using this technique has been demonstrated previously (7).

\section{RESULTS}

Isolate pathogenicity and morphology. Inoculation of silver date palm with isolate 06-59 and cyclamen with isolate 06-69 confirmed that these isolates were responsible for the symptoms observed on nursery plants. At 7 days post inoculation, 3 to 26 lesions were visible per leaf on palm seedlings inoculated with isolate 06-59. At 4 weeks (Fig. 1A), the lesions did not increase in size or number, but setae emerging from necrotic tissue were observed. Isolates with the same morphology as 0659 were recovered from excised lesions at this time. On several leaves of control palm seedlings, a necrotic spot was observed. Setae were not visible on these lesions, nor could an isolate with morphology similar to $06-59$ be recovered. Leaves and flowers from cyclamen plants inoculated with isolate 06-69 developed visible necrotic lesions (Fig. 1B) and 60 to $80 \%$ of flowers were blighted by 10 days post inoculation (Fig. 1C). Also at this time, isolates with the same morphology as 0669 were recovered from excised lesions and setae were observed emerging from necrotic tissue. At 14 days post inoculation, acervuli with abundant spores were visible on lesions on all tissues and symptoms appeared to be spreading. Watertreated cyclamen controls remained healthy. When necrotic host tissues of plants inoculated with both isolates were examined at $\times 400$ magnification, setae bearing conidia were observed (Fig. 1D and $\mathrm{E}$ ).

C. fragariae isolates from strawberry produced conidia that were longer than $C$. gloeosporioides and G. cingulata isolates from strawberry and produced a higher percentage of tapered conidia than the $C$. gloeosporioides and $G$. cingulata isolates (Table 2; Fig. 2A-E). Conidia of the silver date palm and cyclamen isolates were also longer and more frequently tapered than those of $C$. gloeosporioides and $G$. cingulata isolates (Table 2; Fig. 2A, B, C, F, and $\mathrm{G})$. Based on conidium length and the percentage of tapered conidia, the silver date palm and cyclamen isolates could not be differentiated from $C$. fragariae isolates from strawberry (Table 2; Fig. 2D-G). Isolate means for conidium width did not differ between species (Table 2). Cultures of isolates from silver date palm appeared orange, whereas isolates from cyclamen appeared gray or black.

Both isolate (ATS $P<0.001, \mathrm{df}_{\mathrm{N}}=5.16$, $\mathrm{df}_{\mathrm{D}}=20.9$ ) and inoculation date (ATS $P<$ $\left.0.001, \mathrm{df}_{\mathrm{N}}=1.8, \mathrm{df}_{\mathrm{D}}=20.9\right)$ affected the time it took for strawberry plants to collapse but the isolate $x$ inoculation date effect was not significant (ATS $P=0.689$, $\mathrm{df}_{\mathrm{N}}=7.91, \mathrm{df}_{\mathrm{N}}=20.9$ ). The median time required for plants to collapse after inoculation was greater for silver date palm isolate 06-59 than for isolates from strawberry and isolate 06-69 from cyclamen (Table 3). There was no statistical difference in the median time to collapse for plants inoculated with the cyclamen isolate (06-69) and plants inoculated with strawberry isolates. Of 10 plants inoculated with the date palm isolate (06-59), 2 collapsed due to crown rot within 32 days following inoculation, whereas at least 9 of 10 plants inoculated with isolates from strawberry or cyclamen isolate 06-69 collapsed within this time period. When crowns of plants inoculated with 06-59 and alive at 32 days were cut open, a small proportion of the crown tissue was necrotic.

Genetic analysis. There were two substitutions and a 2- or 3-bp insertion of cytosine nucleotides within the ITS1 region that distinguished $C$. fragariae isolates 326-1 and C-16 from strawberry from

Table 2. Dimensions of conidia produced from Colletotrichum fragariae, C. gloeosporioides, or Glomerella cingulata isolated from strawberry, cyclamen, and silver date palm in Florida between 1987 and $2006^{\mathrm{y}}$

\begin{tabular}{|c|c|c|c|c|c|}
\hline \multirow[b]{2}{*}{ Species, isolate (host) } & \multicolumn{2}{|c|}{ Conidium length $(\mu \mathrm{m})$} & \multicolumn{2}{|c|}{ Conidium width $(\mu \mathrm{m})$} & \multirow[b]{2}{*}{ Tapered $(\%)^{\mathbf{z}}$} \\
\hline & Mean & SE & Mean & SE & \\
\hline \multicolumn{6}{|l|}{ C. fragariae } \\
\hline C-16 ( strawberry) & $20.6 \mathrm{a}$ & 0.57 & $5.2 \mathrm{~d}$ & 0.08 & $70 \mathrm{a}$ \\
\hline 06-69 (cyclamen) & $20.4 \mathrm{a}$ & 0.37 & $6.0 \mathrm{a}$ & 0.08 & $66 \mathrm{a}$ \\
\hline 06-59 (silver date palm) & $20.0 \mathrm{a}$ & 0.31 & $5.6 \mathrm{bc}$ & 0.10 & $56 \mathrm{a}$ \\
\hline 326-1 (strawberry) & $19.2 \mathrm{a}$ & 0.97 & $5.5 \mathrm{c}$ & 0.10 & $70 \mathrm{a}$ \\
\hline \multicolumn{6}{|l|}{ C. gloeosporioides } \\
\hline Strawberry-11 (strawberry) & $16.1 \mathrm{~b}$ & 0.26 & $5.8 \mathrm{ab}$ & 0.08 & $26 \mathrm{~b}$ \\
\hline Strawberry-6 (strawberry) & $15.7 \mathrm{bc}$ & 0.21 & $5.8 \mathrm{abc}$ & 0.14 & $22 \mathrm{~b}$ \\
\hline \multicolumn{6}{|l|}{ G. cingulata } \\
\hline 311-1 (strawberry) & $14.9 \mathrm{c}$ & 0.32 & $5.7 \mathrm{abc}$ & 0.13 & $30 \mathrm{~b}$ \\
\hline
\end{tabular}

${ }^{y}$ Means and standard error of means (SE) from measurements of 25 conidia per isolate. Means followed by the same letter are not significantly different, $t$ test $(P>0.05)$.

${ }^{z}$ Percentages of tapered conidia followed by the same letter are not significantly different, $\chi^{2}$ test 1 degree of freedom $(P>0.05)$. Percentages based on morphology of 50 conidia per isolate.

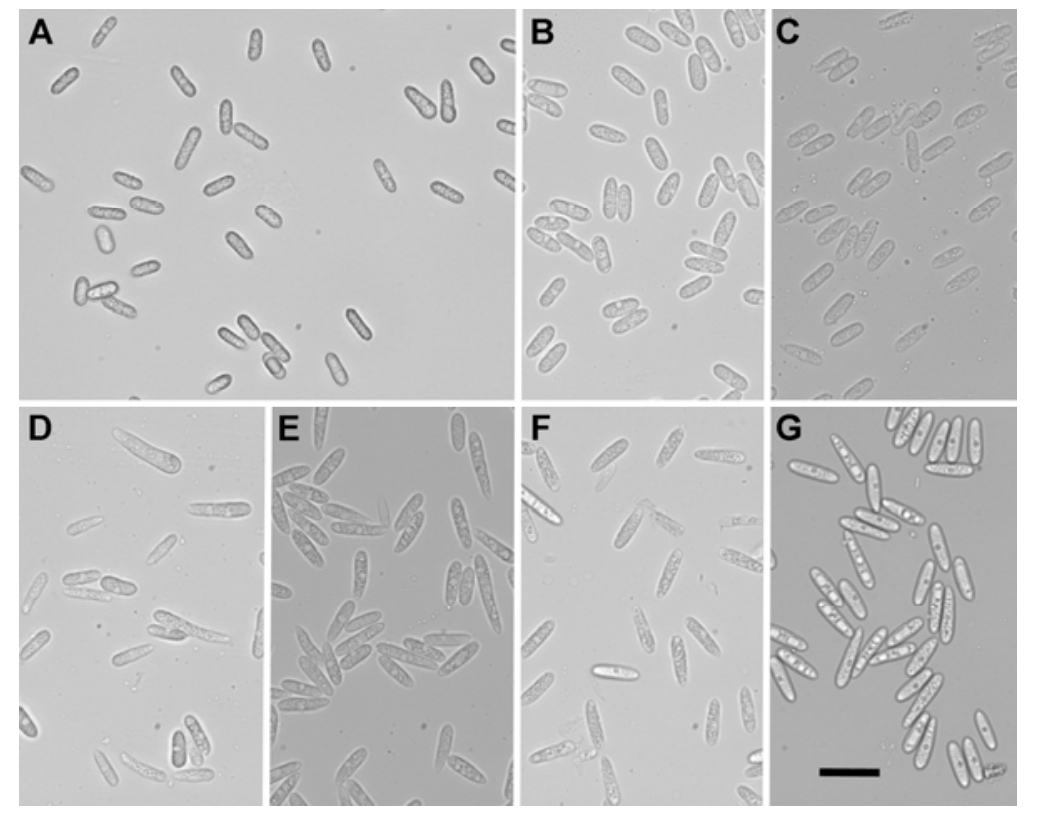

Fig. 2. Conidia of Colletotrichum gloeosporioides/Glomerella cingulata isolates from strawberry: A, 311-1, B, strawberry-11, and C, strawberry-6; C. fragariae isolates from strawberry: D, 326-1 and E, C-16; a $C$. fragariae isolate from silver date palm: F, 06-59; and a $C$. fragariae isolate from cyclamen: G, 06-69. Bar $=25 \mu \mathrm{m}$. All isolates came from plants grown in Florida. 
Table 3. Number of strawberry plants collapsed and the median time it took plants to collapse after injection of crown tissue with conidia from Colletotrichum spp. isolated from strawberry, cyclamen, or silver date palm

\begin{tabular}{|c|c|c|}
\hline Isolate (species, host) ${ }^{x}$ & $\begin{array}{c}\text { Number of } \\
\text { plants collapsed }\end{array}$ & $\begin{array}{c}\text { Median days } \\
\text { to collapse }\end{array}$ \\
\hline Strawberry-6 (Colletotrichum gloeosporioides, strawberry) & 10 & $12 \mathrm{a}$ \\
\hline Strawberry-11 (C. gloeosporioides, strawberry) & 9 & 16 a \\
\hline 06-69 (C. fragariae, cyclamen) & 9 & $16 \mathrm{a}$ \\
\hline C-16 (C. fragariae, strawberry) & 9 & $18 \mathrm{a}$ \\
\hline 311-1 (Glomerella cingulata, strawberry) & 9 & $18 \mathrm{a}$ \\
\hline 326-1 (C. fragariae, strawberry) & 9 & $20 \mathrm{a}$ \\
\hline 06-59 (C. fragariae, silver date palm) & 2 & $>32 \mathrm{~b}$ \\
\hline Water control & 0 & $>32 \mathrm{~b}$ \\
\hline
\end{tabular}

${ }^{x}$ All isolates were collected in Florida between 1987 and 2006.

${ }^{y}$ Number of plants collapsed out of 10 at 32 days past the date of inoculation, the time point when the experiment was terminated.

${ }^{\mathrm{z}}$ Days to collapse was $>32$ if a plant remained alive at 32 days past the date of inoculation. Median times followed by the same letter are not significantly different $(P>0.05)$ based on $P$ values for analysis of variance-type statistics (20) obtained from pairwise contrasts evaluating days to collapse for plants inoculated on three different dates.
C. gloeosporioides isolates and the $G$. cingulata isolate from strawberry (Fig. 3). Five polymorphic sites were found within the ITS1 and ITS2 regions among the two $C$. gloeosporioides isolates and the $G$. cingulata isolate and at least one of the isolates had the same base pair at these sites as the $C$. fragariae isolates. The $5.8 \mathrm{~S}$ rRNA gene sequence was the same for all isolates. The only difference between isolates 326-1 and C-16 within ITS regions was the size of the cytosine insertion in the ITS1 region: the insertion was $2 \mathrm{bp}$ for $326-1$ and 3 bp for C-16. The silver date palm isolate (06-59) and the cyclamen isolate (06-69) had ITS sequences identical to isolate $\mathrm{C}-16$ from strawberry.

There were four distinct AT-rich DNA banding patterns observed among the iso-

\begin{tabular}{|c|c|c|c|c|c|}
\hline \multirow[t]{2}{*}{ Isolate } & \multicolumn{5}{|c|}{ Nucleotide Sequences } \\
\hline & \multicolumn{5}{|c|}{ ITS1 } \\
\hline $326-1$ & CTGAGTTTAC & GCTCTACAAC & CCTTTGTGAA CATACCTACA & ACTGTTGCTT & CGGCGGGTAG \\
\hline $\mathrm{C}-16$ & 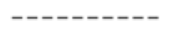 & ---------- & - - & $----1--1$ & ---------- \\
\hline $06-59$ & --------- & --------- & --------- --------- & --------- & --------- \\
\hline $06-69$ & -------- & --------- & 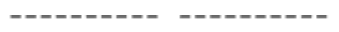 & --------- & --------- \\
\hline $311-1$ & --------- & $------\mathrm{T}---$ & 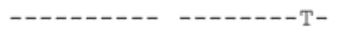 & -------1 & -------- \\
\hline Strawberry-11 & --------- & --------- & 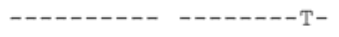 & --------1 & -------- \\
\hline Strawberry-6 & \multicolumn{5}{|c|}{$\operatorname{ITS} 1$} \\
\hline $326-1$ & GGTCECCGTG & ACCCTCCCGG & $\mathrm{CCTCCCGCCC} \mathrm{CCCC}^{\star} \mathrm{GGGCG}$ & GGTCGGCGCC & CGCCGGAGGA \\
\hline $\mathrm{C}-16$ & $---n---1$ & $----n---1$ & $-------------C----$ & $-----n-1$ & $----n--n$ \\
\hline $06-59$ & --------- & --------- & $--------------C----$ & --------- & --------- \\
\hline $06-69$ & -------- & -------- & $---------\quad----\mathrm{C}-----$ & --------- & -------- \\
\hline $311-1$ & $----\mathrm{T}---\mathrm{C}-$ & $----2--1$ & $---------\mathrm{T} \quad--\star \star \star------$ & -------- & --------2 \\
\hline Strawberry-11 & $----\mathrm{T}-----$ & --------1 & $----------\quad--\star \star *-----$ & -------- & --------- \\
\hline Strawberry-6 & \multicolumn{5}{|c|}{ ITS 1} \\
\hline $326-1$ & TAACCAAACT & CTGATTTAAC & GACGTTTCTT CTGAGTGGTA & CAAGCAAATA & ATCA \\
\hline $\mathrm{C}-16$ & -------- & -------- & 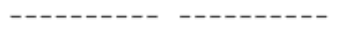 & ------- & --- \\
\hline $06-59$ & $----1--1$ & --------1 & 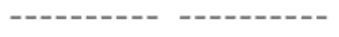 & $------1-4$ & ---- \\
\hline $06-69$ & ------- & -------- & 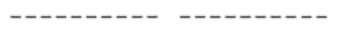 & -------- & --- \\
\hline $311-1$ & ------- & --------1 & 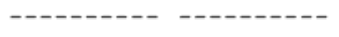 & -------- & --- \\
\hline Strawberry-11 & 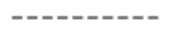 & 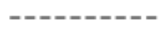 & 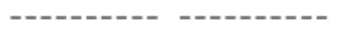 & 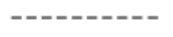 & --- \\
\hline \multirow[t]{3}{*}{ Strawberry-6 } & ------- & -------- & 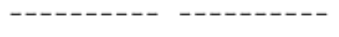 & -------- & ---- \\
\hline & ------- & -------- & 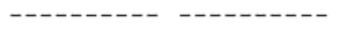 & ------- & --- \\
\hline & \multicolumn{5}{|c|}{ ITS2 } \\
\hline $326-1$ & САACCCTCAA & GCTCTGCTTG & GTGTTGGGGC CCTACAGCTG & ATGTAGGCCC & TCAAAGGTAG \\
\hline $\mathrm{C}-16$ & -------- & ----n---n & 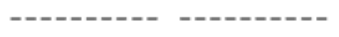 & -------4 & $------n$ \\
\hline $06-59$ & - - - - - & -----n--- & - - & 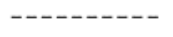 & --------1 \\
\hline $06-69$ & --1--n-- & 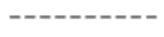 & 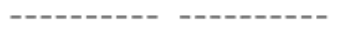 & -------- & 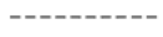 \\
\hline $311-1$ & -------- & 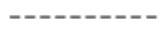 & 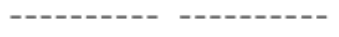 & $-----1-4$ & 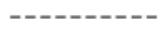 \\
\hline Strawberry-11 & ------- & -------- & 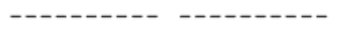 & ------- & -------- \\
\hline Strawberry-6 & \multicolumn{5}{|c|}{ ITS2 } \\
\hline $326-1$ & TGGCGGACCC & TCCCGGAGCC & TCCTTTGCGT AGTAACTTTA & CGTCTCGCAC & TGGGATCCGG \\
\hline $\mathrm{C}-16$ & ---n---n- & 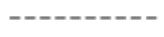 & 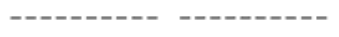 & 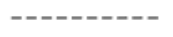 & --------- \\
\hline $06-59$ & -------1 & --------1 & 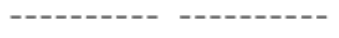 & -------1 & --------2 \\
\hline $06-69$ & -------- & --------- & 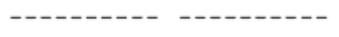 & -------- & --------- \\
\hline $311-1$ & ---------- & ---------- & 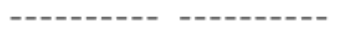 & 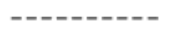 & --------- \\
\hline Strawberry-11 & ------- & -------- & 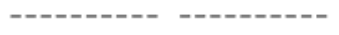 & --------- & ---1-n-n \\
\hline Strawberry-6 & \multicolumn{5}{|c|}{$\operatorname{ITS} 2$} \\
\hline $326-1$ & AGGGACTCTT & GCCGTAAAAC & CCCCCAATTT TCCAAAG & & \\
\hline $\mathrm{C}-16$ & --------- & --------- & $----------\quad-------$ & & \\
\hline $06-59$ & -------- & -------- & 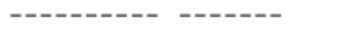 & & \\
\hline $06-69$ & ------- & -------- & 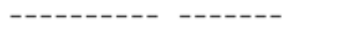 & & \\
\hline $311-1$ & $-----1--4$ & 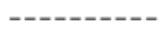 & 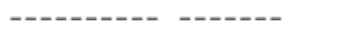 & & \\
\hline Strawberry-11 & -------- & --------- & $----{ }^{*}-----\quad-------$ & & \\
\hline Strawberry-6 & ---------- & ---------- & $----*-----\quad-------$ & & \\
\hline
\end{tabular}

Fig. 3. Nucleotide sequence from the internal transcribed spacer (ITS) 1 and ITS2 region of the rDNA repeat for Colletotrichum fragariae isolates 326-1 and C-16 from strawberry, C. fragariae isolate 06-59 from silver date palm, C. fragariae isolate 06-69 from cyclamen, Glomerella cingulata isolate 311-1 from strawberry, and $C$. gloeosporioides isolates strawberry-11 and strawberry-6 from strawberry. All isolates came from plants grown in Florida. Underlined nucleotides in the sequence for reference isolate 326-1 show the three sites that distinguish C. fragariae isolates from G. cingulata and C. gloeosporioides isolates; * indicates a deletion. 
lates (Fig. 4). The homothallic G. cingulata isolate had a unique DNA banding pattern that was previously described as a Cgl-1-type pattern (7). Isolates strawberry11 and strawberry- 6 had Cgl-2-type banding patterns (7). The $C$. fragariae isolates from strawberry had identical AT-rich DNA fingerprints that were distinct from the $C$. gloeosporioides/G. cingulata isolates and the fingerprints matched the ATrich DNA fingerprint of isolate 06-69 from cyclamen. Isolate 06-59 from silver date palm had a unique AT-rich DNA fingerprint from all of the other isolates.

\section{DISCUSSION}

Conidial shape, conidial size, and the presence or absence of setae bearing conidia are important morphological characteristics for differentiating $C$. fragariae isolates from $C$. gloeosporioides isolates on strawberry (10). C. fragariae produces conidia that are longer, has a high proportion of tapered conidia, and bears conidia on setae. These morphological characteristics were observed for the two Colletotrichum strains isolated from diseased silver date palm and cyclamen in addition to the reference $C$. fragariae isolates from strawberry. Sequence data from the ITS region of the rDNA repeat of the silver date palm and cyclamen isolates were also identical to one of the $C$. fragariae isolates from strawberry. The isolates should be included in the species group C. fragariae, given that similarity of genetic and morphological characteristics takes precedence over host specificity when assigning an isolate to a species group.

Freeman et al. (7) published AT-rich DNA banding patterns for multiple Colletotrichum isolates using the enzyme HaeIII. C. fragariae isolates from strawberry were virtually identical to one another in that study, with an average similarity among C. fragariae isolates of $96 \%$. Similarity among isolates within Colletotrichum spp. ranged from 86 to $100 \%$ in that study. In the present study, AT-rich banding patterns of isolate 326-1 and C-16 from strawberry were also identical to one another and to that of isolate 06-69 from cyclamen. Using the same measure of similarity reported by Freeman et al. (7), the similarity of AT-rich DNA bands between isolate 06-59 from silver date palm and $C$. fragariae isolates from strawberry was only $7 \%$. This indicates that the date palm isolate is distinct from the $C$. fragariae isolates that infect strawberry.

Isolate 06-69 from cyclamen appears to be from the same $C$. fragariae group that infects strawberry. In addition to possessing morphological characteristics and rDNA sequence data identical to $C$. fragariae isolates from strawberry, it was pathogenic to strawberry and had an ATrich DNA banding pattern identical to that of strawberry isolates. An AT-rich DNA banding pattern identical to strawberry isolates is particularly good evidence, because the effectiveness of AT-rich DNA banding patterns in differentiating infraspecific populations of $C$. gloeosporioides on strawberry and host-specific populations of $C$. graminicola approximates that of RAPD markers (7). The finding that a C. fragariae isolate from a host other than strawberry is so closely related to isolates from strawberry suggests that migration of C. fragariae from strawberry could produce an economically important disease on another crop. However, we cannot conclude that isolate 06-69 migrated from strawberry because the nursery with the diseased cyclamen plants was more than $20 \mathrm{~km}$ from a commercial strawberry field. The cyclamen plants were previously imported into Florida from a flower grower in California as seed-propagated plug plants. C. fragariae is present in California $(7,10)$, but the grower who provided the plugs produced only ornamental flowers. Also, cyclamen was inoculated with strawberry isolate 326-1 and symptoms were observed on flowers; however, they were not as severe as those on plants inoculated with isolate 06-69 from cyclamen (data not shown). Although two strawberry plants did collapse when inoculated with the silver date palm isolate, the rate at which necrosis developed within crowns of most plants suggests that this strain is not likely to cause crown rot epidemics on strawberry. The absence of the AT-rich DNA banding pattern of this strain among isolates from field-infected plants supports this conclusion (7).

C. fragariae has been described previously as a mostly host-specific species (21). However, there is some evidence that isolates described as C. gloeosporioides from hosts other than strawberry might actually be $C$. fragariae. Type B C. gloeosporioides isolates from Stylosanthes guianensis (Aublet) Sw. bear conidia on setae (13), produce proportionately more tapered conidia than type A isolates from Stylosanthes spp. (17), and group with a $C$. fragariae isolate in a phylogeny constructed from the ITS1 region (18). Although type A isolates have sterile setae and produce mostly cylindrical conidia (13), they also group with a $C$. fragariae isolate based on ITS1 sequence data in a description of infraspecific groups of $C$. gloeosporioides on Stylosanthes spp. (18). Munaut et al. (18) questioned whether the C. fragariae sequence (GenBank accession number Z32943) used in their study was from a correctly identified isolate. This sequence was compared with a sequence from a reference $C$. fragariae isolate from the present study, and it differed by only a single deletion. The $C$. fragariae sequence used by Munaut et al. (18), along with sequences from type $\mathrm{A}$ and $\mathrm{B} C$. gloeosporioides isolates, possessed the two nucleotide substitutions and the cytosine insert that distinguish $C$. fragariae isolates from C. gloeosporioides isolates on strawberry. The various hosts and origins clade described by Munaut et al. (18), which contained a group of isolates different from those described as type A and B isolates from Stylosanthes spp., would include the $C$. gloeosporioides/G. cingulata isolates in the present study. Also based on sequence data similarity, $C$. gloeosporioides isolates from Limonium spp. grouped with $C$. fragariae from strawberry in a phylogeny constructed from ITS sequence data but the isolates did not bear conidia on setae and produced conidia with morphological characteristics typical of most C. gloeosporioides isolates (16). The occurrence of isolates with typical $C$. gloeosporioides morphology that group more closely with $C$. fragariae suggests

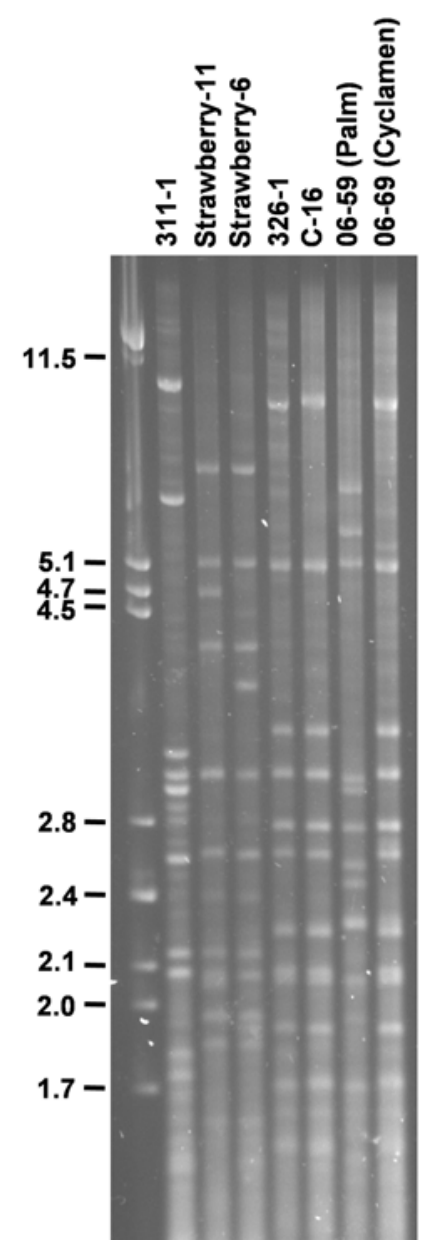

Fig. 4. Labeled lanes contain total DNA from Glomerella cingulata isolate 311-1 from strawberry, Colletotrichum gloeosporioides isolates strawberry-11 and strawberry-6 from strawberry, C. fragariae isolates 326-1 and C-16 from strawberry, C. fragariae isolate 06-59 from silver date palm, and $C$. fragariae isolate 06-69 from cyclamen digested with the restriction enzyme HaeIII. All isolates came from plants grown in Florida. The lane at the far left contains PstI-digested $\lambda$ DNA which was used as a size marker. Numbers on the left side of the gel are the size of marker bands in kilobases. Bright bands in lanes containing HaeIII-digested DNA are primarily of mitochondrial origin (30) and are referred to as AT-rich bands in the text. 
that phialidic setae and tapered conidia might be recently derived characteristics present among a subset of isolates within the $C$. gloeosporioides/G. cingulata species aggregate. Thus, it might be appropriate to describe $C$. fragariae using an infraspecific designation of $C$. gloeosporioides similar to that used by Munaut et al. (18) to describe infraspecific populations on Stylosanthes spp.

Cyclamen anthracnose caused by $G$. cingulata or C. gloeosporioides is a welldescribed disease (6), and it has been confirmed that $C$. gloeosporioides causes a leaf spot on pygmy date palm $(P$. roebelenii O'Brien; 26). Given the confusion regarding the taxonomy of $C$. gloeosporioides and $C$. fragariae, it is possible that $C$. fragariae is also commonly associated with these diseases. In 2006, cyclamen anthracnose caused by a Glomerella sp. or a Colletotrichum sp. was reported in Florida, Texas, and California (A. R. Chase, personal communication). It had not been a major problem in prior years. Anthracnose did not recur in the nursery that provided the cyclamen sample during the 2007 season. However, the grower applied azoxystrobin as a prophylactic to prevent its occurrence. Leaf spots on seedlings were still present in the nursery with infected date palm during spring 2008, but the grower did not believe the disease warranted any control measures not already in place.

\section{ACKNOWLEDGMENTS}

We thank C. Moyer, T. Hasing, and J. Antonio Mangandi Sánchez for helping conduct pathogenicity assays and preparing DNA templates for sequencing.

\section{LITERATURE CITED}

1. Brooks, A. N. 1931. Anthracnose of strawberry caused by Colletotrichum fragariae, n. sp. Phytopathology 21:739-744.

2. Brooks, A. N. 1935. Anthracnose and wilt of strawberry caused by Colletotrichum fragariae. (Abstr.) Phytopathology 25:973.

3. Brunner, E., Dette, H., and Munk, A. 1997. Boxtype approximations in nonparametric factorial designs. J. Am. Stat. Assoc. 92:1494-1502.

4. Buddie, A. G., Martínez-Culebras, Bridge, P. D., García, M. D., Querol, A., Cannon, P. F., and Monte, E. 1999. Molecular characterization of Colletotrichum strains derived from strawberry. Mycol. Res. 103:385-394.

5. Cannon, P. F., Bridge, P. D., and Monte, E. 2000. Linking the past, present, and future of Colletotrichum systematics. Pages 1-20 in:
Colletotrichum: Host Specificity, Pathology, and Host-Pathogen Interaction. D. Prusky, S. Freeman, and M. B. Dickman, eds. American Phytopathological Society Press, St. Paul, MN.

6. Daughtrey, M. L., Wick, R. L., and Peterson, J. L. 1995. Compendium of Flowering Potted Plant Diseases. American Phytopathological Society, St. Paul, MN.

7. Freeman, S., Pham, M., and Rodriguez, R. J. 1993. Molecular genotyping of Colletotrichum species based on arbitrarily primed PCR, A+Trich DNA, and nuclear DNA analyses. Exp. Mycol. 17:309-322.

8. Freeman, S., and Rodriquez, R. J. 1995. Differentiation of Colletotrichum species responsible for anthracnose of strawberry by arbitrarily primed PCR. Mycol. Res. 99:501-504.

9. Georgiev, O. I., Nikolaev, N., Hadjiolov, A. A., Skryabin, K. G., Zakharyev, V. M., and Bayev, A. A. 1981. The structure of the yeast ribosomal RNA genes. 4. Complete sequence of the $25 \mathrm{~S}$ rRNA gene from Saccharomyces cerevisiae. Nucleic Acids Res. 9:6953-6958.

10. Gunnell, P. S., and Gubler, W. D. 1992. Taxonomy and morphology of Colletotrichum species pathogenic to strawberry. Mycologia 84:157-165.

11. Howard, C. M., and Albregts, E. E. 1973. Cassia obtusifolia, a possible reservoir for inoculum of Colletotrichum fragariae. Phytopathology 63:533-534.

12. Howard, C. M., and Albregts, E. E. 1984. Anthracnose of strawberry fruit caused by Glomerella cingulata in Florida. Plant Dis. 68:824-825.

13. Irwin, J. A. G., and Cameron, D. F. 1978. Two diseases in Stylosanthes spp. caused by Colletotrichum gloeosporioides in Australia, and pathogenic specialization within one of the causal organisms. Aust. J. Agric. Res. 29:305317.

14. MacKenzie, S. J., Legard, D. E., Timmer, L. W., Chandler, C. K., and Peres, N. A. 2006. Resistance of strawberry cultivars to crown rot caused by Colletotrichum gloeosporioides isolates from Florida is nonspecific. Plant Dis. 90:1091-1097.

15. MacKenzie, S. J., Seijo, T. E., Legard, D. E., Timmer, L. W. and Peres, N. A. 2007. Selection for pathogenicity to strawberry in populations of Colletotrichum gloeosporioides from native plants. Phytopathology 97:1130-1140.

16. Maymon, M., Zveibil, A., Pivonia, S., Minz, D., and Freeman, S. 2006. Identification and characterization of benomyl-resistant and -sensitive populations of Colletotrichum gloeosporioides from Statice (Limonium spp.). Phytopathology 96:542-548.

17. Munaut, F., Hamaide, N., and Maraite, H. 2001. Molecular and morphological characterization of Colletotrichum gloeosporioides from native Mexican Stylosanthes species. Plant Pathol. 50:383-396.

18. Munaut, F., Hamaide, N., and Maraite, H. 2002. Genomic and pathogenic diversity in Colletotrichum gloeosporioides from wild native Mexican Stylosanthes spp., and taxonomic implications. Mycol Res. 106:579-593.

19. Selker, E., and Yanofsky, C. 1979. Nucleotide sequence and conserved features of the $5.8 \mathrm{~S}$ rRNA coding region of Neurospora crassa Nucleic Acids Res. 6:2561-2567.

20. Shaw, D. A., and Madden, L. V. 2004. Nonparametric analysis of ordinal data in designed factorial experiments. Phytopathology 94:3343.

21. Smith, B. J. 1998. Anthracnose crown rot. Pages 46-48 in: Compendium of Strawberry Diseases, 2nd ed. J. L. Maas, ed. American Phytopathological Society, St. Paul, MN

22. Sogin, M. L., Miotto, K., and Miller, L. 1986. Primary structure of the Neurospora crassa small subunit ribosomal RNA coding region. Nucleic Acids Res. 14:9540.

23. Sreenivasaprasad, S., Brown, A. E., and Mills, P. R. 1992. DNA sequence variation and interrelationships among Colletotrichum species causing strawberry anthracnose. Physiol. Mol. Plant Pathol. 41:265-281.

24. Sreenivasaprasad, S., Mills, P. R., Meehan, B. M., and Brown, A. E. 1996. Phylogeny and systematic of 18 Colletotrichum species based on ribosomal DNA spacer sequences. Genome 39:499-512.

25. Thompson, J. D., Higgins, D. G., and Gibson, T. J. 1994. CLUSTAL W: improving the sensitivity of progressive multiple sequence alignment through sequence weighting, positionspecific gap penalties and weight matrix choice. Nucleic Acids Res. 22:4673-4680.

26. Uchida, J. Y. 2004. Colletotrichum leaf and fruit spot. Pages 14-15 in: Compendium of Ornamental Palm Diseases and Disorders. M. L. Elliot, T. K. Broschat, J. Y. Uchida, and G. W. Simone, eds. American Phytopathological Society, St. Paul, MN.

27. Ureña-Padilla, A. R., MacKenzie, S. J., Bowen, B. W., and Legard, D. E. 2002. Etiology and population genetics of Colletotrichum spp. causing crown and fruit rot of strawberry. Phytopathology 92:1245-1252.

28. Villanueva-Arce, R., Hernández-Anguiano, A. M., Yáñez-Morales, M de J., Téliz-Ortíz, D., Mora-Aguilera, A., Cárdenas-Soriano, E., and Castañeda-Vildózola, Á. 2005. Characterization and identification of Colletotrichum fragariae on cherimoya fruits. Agrociencia 39:93106.

29. White, T. J., Bruns, T., Lee, S., and Taylor, J. 1990. Amplification and direct sequencing of fungal ribosomal RNA genes for phylogenetics. Pages 315-322 in: PCR Protocals: A Guide to Methods and Application. M. A. Innis, D. H. Gelfand, J. J. Sninsky, and T. J. White, eds. Academic Press, San Diego, CA.

30. Wingfield, B. D., Harrington, T. C., and Steimel, J. 1996. A simple method for detection of mitochondrial DNA polymorphisms. Fungal Genet. Newsl. 43:56-60.

31. Xiao, C. L., MacKenzie, S. J., and Legard, D. E. 2004. Genetic and pathogenic analyses of Colletotrichum gloeosporioides isolates from strawberry and noncultivated hosts. Phytopathology 94:446-453. 